\title{
A Cristologia Existencial de Karl Rahner e de Teresa de Calcutá Dois místicos do século sem Deus
}

Orientadora: Maria Clara Lucchetti Bingemer

Doutorando: Douglas Alves Fontes

Área de Concentração: Teologia Sistemático-Pastoral

Linha de Pesquisa: Religião e Modernidade

Projeto de Pesquisa: Literatura contemporânea e pensamento teológico

A cristologia existencial de Karl Rahner e de Teresa de Calcutá é uma pesquisa cujo objetivo é apresentar, de modo comparativo, esses dois grandes místicos do século sem Deus (XX). O trabalho se estrutura em cinco momentos. Primeiro, é apresentada a vida do teólogo alemão que dá a tônica para o trabalho. Em seguida, a cristologia de Karl Rahner, a partir da qual descrevemos a proposta de uma nova reflexão cristológica para a atualidade, segundo o próprio teólogo. Da mesma forma, explicitamos as duas vertentes cristológicas, pensadas desde a relação com a pessoa de Jesus Cristo e tratadas por Karl Rahner, tanto a descendente, quanto a vertente ascendente. No terceiro momento, é apresentada a vida de Teresa de Calcutá - como foi a de Rahner - a partir da sua experiência espiritual. Em seguida, a cristologia de Madre Teresa é descrita e orientada com base em alguns teólogos, que oferecem luzes para a compreensão do pensamento dessa mulher que pode e será considerada uma teóloga. O último momento da pesquisa será estruturado numa perspectiva comparativa. Rahner e Teresa de Calcutá serão vistos a partir das consequências da chamada cristologia existencial, que afetam a reflexão teológica. Como via de aplicação, o pensamento do Papa Francisco será usado, de modo que se perceba o quanto a reflexão dos místicos pode contribuir para a renovação da teologia e, por consequência, da vida eclesial, nos dias atuais. Dessa maneira, a cristologia existencial de Karl Rahner e de Teresa de Calcutá oferecerá luzes para o ser cristão no século XXI.

Palavras-chave: Jesus Cristo. Karl Rahner. Teresa de Calcutá. 